\title{
MEMBANGUN LOYALITAS PELANGGAN PDAM KOTA SALATIGA DENGAN KUALITAS PELAYANAN MELALUI KEPUASAN
}

\author{
Septian Eka Putra \\ Program Magister Manajemen STIE “AUB” Surakarta \\ Email: yanz.putra2709@gmail.com
}

\begin{abstract}
ABSTRAK
Penelitian ini bertujuan untuk mengetahui, menguji dan menganalisis pengaruh keberwujudan, keandalan, ketanggapan, jaminan, kepedulian terhadap loyalitas pelanggan dengan kepuasan sebagai variabel intervening pada Kantor PDAM Kota Salatiga. Teknik analisis data yang digunakan adalah analisis jalur, dimana akan diuji dengan uji t, uji $\mathrm{F}$ dan uji $\mathrm{R}^{2}$, Correlations, pengaruh langsung dan pengaruh tidak langsung dan total pengaruh. Teknik pengumpulan data dengan menggunakan kuesioner. Pengambilan sampel menggunakan teknik sampling dan ditetapkan sebanyak 10\% dari populasi, dengan perhitungan: $1196 \times 10 \%=119,6$ dibulatkan menjadi 120 sampel. Hasil uji t menunjukkan keberwujudan ketanggapan jaminan berpengaruh positif dan signifikan terhadap kepuasan sedangkan keandalan dan kepedulian berpengaruh negatif dan tidak signifikan terhadap kepuasan; keandalan, jaminan kepedulian dan kepuasan berpengaruh positif dan signifikan terhadap loyalitas dan ketanggapan berpengaruh negatif dan signifikan terhadap loyalitas sedangkan keberwujudan berpengaruh positif dan tidak signifikan terhadap loyalitas. Dari hasil koefisien determinasi total dapat dijelaskan bahwa Nilai $\mathrm{R}^{2}$ total sebesar 0,919 dapat diartikan variasi loyalitas dijelaskan oleh variabel keberwujudan, keandalan, ketanggapan, jaminan, kepedulian, dan kepuasan pelanggan sebesar 91,9\% sisanya sebesar 7,1\% dijelaskan oleh variabel lain di luar model penelitian, seperti lokasi, harga dan lain-lain. Dari hasil uji F test bahwa model regresi dapat dipakai untuk memprediksi loyalitas atau dengan kata lain kepuasan, kepedulian, keberwujudan, ketanggapan, keandalan, jaminan secara simultan/bersama-sama berpengaruh signifikan terhadap loyalitas. Hasil analisis jalur dapat diketahui bahwa pengaruh langsung jaminan terhadap loyalitas merupakan jalur yang paling efektif atau dominan untuk meningkatkan loyalitas karena memiliki nilai kooefisien terbesar diantara yang lain.

Kata Kunci : keberwujudan, keandalan, ketanggapan, jaminan, kepedulian, kepuasan dan loyalitas..
\end{abstract}

\begin{abstract}
This study aims to determine, test and analyze the effect of manifestation, reliability, responsiveness, assurance, concern for customer loyalty with satisfaction as an intervening variable at the Salatiga City PDAM Office. The data analysis technique used is path analysis, which will be tested by $\mathrm{t}$ test, $\mathrm{F}$ test and $\mathrm{R}^{2}$ test, Correlations, direct effects and indirect and total effects. Data collection techniques using a questionnaire. Sampling using a sampling technique and determined as much as $10 \%$ of the population, with the calculation: $1196 \times 10 \%=119.6$ rounded up to 120 samples. $T$ test results show the realization of guarantee responsiveness has a positive and significant effect on satisfaction while reliability and caring have a negative and not significant effect on satisfaction; reliability, care and satisfaction guarantees a positive and significant effect on loyalty and responsiveness have a negative and significant effect on loyalty while manifestation has a positive and not significant effect on loyalty. From the results of the total determination coefficient can be explained that the total $\mathrm{R}^{2}$ value of 0.919 can be interpreted as variations in loyalty explained by the variables of manifestation, reliability, responsiveness, assurance, care, and customer satisfaction by $91.9 \%$ the remaining $7.1 \%$ is explained by other variables outside research models, such as location, price and others. From the results of the F test that the regression model can be used to predict loyalty or in other words satisfaction, caring, manifestation, responsiveness, reliability, guarantee simultaneously / together have a significant effect on loyalty. The path analysis results can be seen that the direct effect of guarantees on loyalty is the most effective or dominant pathway to increase loyalty because it has the largest coefficient value among others.
\end{abstract}

Keywords: manifestation, reliability, responsiveness, assurance, caring, satisfaction and loyalty.

\section{PENDAHULUAN}

Air merupakan kebutuhan pokok bagi seluruh mahluk hidup di dunia ini termasuk manusia. Tanpa air, manusia akan mengalami kesulitan dalam melangsungkan hidupnya, maka dari itu pengolahannya harus diatur sedemikian rupa sehingga agar dapat dimanfaatkan secara efektif dan efisien. Air adalah sumber daya nasional yang menyangkut hajat hidup orang banyak, maka pengolahannya diatur dan pegang oleh pemerintah hal ini sesuai dengan UUD 1945 Pasal 33 ayat (3) yang berbunyi sebagai berikut : "bumi dan air dan kekayaan alam yang terkandung di dalamnya dikuasai oleh Negara dan dipergunakan untuk sebesar besarnya kemakmuran rakyat". 
Pemerintah daerah Kota Salatiga berwenang mengelola sumber regional yang tersedia di wilayahnya dan bertanggung jawab memelihara kelestarian lingkungan sesuai dengan peraturan perundang-undangan. Sebagai bentuk penyerahan sebagian urusan pemerintah dibidang pekerjaan umum kepada daerah. Selanjutnya, melalui peraturan daerah pelaksanaannya diserahkan kepada seluruh instansi. Dalam hal ini instansi yang mengenai adalah (Perusahaan Daerah Air Minum) PDAM, dimana PDAM merupakan Badan Usaha Milik Daerah (BUMD).

PDAM merupakan perusahaan yang bergerak dibidang jasa penyedia air bersih. Salah satu tujuan dibentuknya PDAM adalah mencukupi kebutuhan masyarakat akan air bersih, pengembangan sarana dan prasanana serta distribusi air bersih, sedang tujuan lainnya adalah ikut serta mengembangkan perekonomian guna menunjang pembangunan daerah dengan memperluas lapangan pekerjaan, serta mencari laba sebagai sumber utama pembiayaan bagi daerah.

Fasilitas air bersih yang harus dipenuhi, diperlukan juga pelayanan yang baik untuk mendukung fasilitas air yang telah disediakan. Pelayanan adalah setiap tindakan atau kegiatan yang dapat ditawarkan oleh suatu pihak kepada pihak lain, yang pada dasarnya tidak berwujud dan tidak mengakibatkan kepemilikan apapun, produksinya dapat dikaitkan dan tidak dikaitkan pada satu produk fisik. Pelayanan merupakan perilaku produsen dalam rangka memenuhi kebutuhan dan keinginan konsumen demi tercapainya kepuasan pelanggan itu sendiri (Kotler, 2013).

Pelayanan harus dilakukan dengan optimal, oleh karena itu dalam suatu perusahaan air minum Kota Salatiga harus memiliki strategi yang khusus untuk mengelola jasa dengan baik. Strategi khusus yang dimaksudkan mengenai tentang hal apa yang dapat mempengaruhi kepuasan pelanggan dan loyalitas pelanggan, hal itu berkaitan dengan kualitas pelayanan dimana kualitas pelayanan merupakan aspek terpenting untuk mencapai kepuasan pelanggan dan loyalitas pelanggan, untuk itu perlu dikaji tentang kualitas pelayanan secara menyeluruh.

Kualitas pelayanan yang baik dan sesuai dengan harapan masyarakat, diharapkan dapat memberikan dampak positif bagi pihak-pihak yang terkait baik itu masyarakat ataupun pihak PDAM. Pelayanan tersebut kini menjadi hal yang penting bagi masyarakat, apabila mereka mendapat pelayanan yang buruk, maka mereka tidak akan betah untuk tetap bekerjasama dengan peruhaan dan memilih untuk berhenti menggunakan layanan tersebut, sehingga hal itu menimbulkan kekecewaan pada masyarakat. Pelayanan yang baik dalam sebuah organisasi sangat dibutuhkan, dengan adanya pelayanan yang baik dan respon positif dari masyarakat berupa kepuasan, maka akan membentuk suatu kenyamanan yang berujung loyalitas masyarakat (Lupiyoadi, 2013).

Pengaruh ini didukung oleh hasil penelitian Semuel dan Wijaya (2011), Karsono (2015), Halim (2013), Suasana dkk (2013) yang menunjukkan bahwa kualitas pelayanan yang terdiri dari keberwujudan, keandalan, ketanggapan, jaminan, kepedulian berpengaruh terhadap loyalitas

Fenomena yang terjadi mengenai jasa pelayanan PDAM di Kota Salatiga kurangnya partisipasi dalam masalah pelayanan persediaan air minum sehingga perlu pelayanan yang maksimal. Salah satu indikator keberhasilan pelayanan adalah kepuasan pelanggan. Kepuasan merupakan fungsi dari kesan kinerja dan harapan, pelanggan akan merasa puas apabila kinerja layanan jasa yang diperolehnya sama atau melebihi harapan pelanggan dan sebaliknya, ketidakpuasan atau perasaan kecewa pelanggan akan muncul apabila kinerja layanan yang diperolehnya itu tidak sesuai dengan harapannya (Pohan, 2013).

Kepuasan pelanggan PDAM di Kota Salatiga mempunyai kaitan yang sangat erat dengan persepsi pelanggan terhadap suatu produk atau jasa penyedia air minum yang ditawarkan. Persepsi pelanggan tersebut akan dipengaruhi oleh kualitas produk (air minum) serta kepuasan pelanggan. Jika harapan pelanggan terlalu tinggi, tetapi tidak dapat dipenuhi oleh suatu produk atau jasa, maka produk atau jasa tersebut tidak akan memuaskan pelanggan. Menurut Henning dan Klee (2012:45), kepuasan pelanggan secara positif akan mempengaruhi kepuasan pelanggan untuk setia. Dari kepuasan tersebut 
akan berdampak kepada pelanggan untuk setia atau loyal terhadap Kantor PDAM Kota Salatiga. Menurut (Kotler, 2013), Loyalitas atau kesetiaan dijelaskan sebagai komitmen yang dipegang kuat untuk membeli atau berlangganan lagi produk atau jasa tertentu di masa depan. Loyalitas pelanggan akan menjadi kunci sukses, tidak hanya dalam jangka pendek tetapi keunggulan bersaing secara berkelanjutan, meskipun ada pengaruh situasi dan usaha pemasaran yang berpotensi menyebabkan perubahan perilaku. Tingkat kepuasan dan loalitas pelanggan yang tinggi akan menyebabkan suatu penguatan positif yang berulang yang akhirnya akan menciptakan hubungan emosional antara pelanggan dan penyedia jasa air minum.

Menurut Supranto (2011:71), dua hal yang perlu diperhatikan dalam mempertahankan menarik pelanggan agar selalu merasa puas dan berdampak pada loyalitas pelanggan, yang pertama adalah dengan memberikan kualitas pelayanan yang meliputi aspek keberwujudan, keandalan, ketanggapan, jaminan dan kepedulian. Sedangkan yang kedua adalah dengan menerapkan kebijakan harga yang terjangkau dan sesuai dengan kualitas produk dan jasa air minum yang diberikan kepada pelanggan.

Kepuasan pelanggan merupakan salah satu hasil penting dari semua aktivitas pemasaran, sebab kepuasan pelanggan akan berdampak pada keberhasilan perusahaan. Oleh karena itu perusahaan selalu berusaha untuk dapat memuaskan pelanggan. Tjiptono (2012:99) menyatakan bahwa kepuasan atau ketidakpuasan pelanggan adalah respon pelanggan terhadap evaluasi ketidakpuasan yang dirasakan antara harapan sebelumnya dan loyalitas pelanggan aktual produk setelah pemakaiannya. Kepuasan diukur dari sebaik apa harapan pelanggan dipenuhi, sedangkan loyalitas pelanggan adalah ukuran semua apa pelanggan melakukan pembelian ulang. Sehingga kepuasan pelanggan dirasakan berhubungan dengan loyalitas pelanggan.

Kotak saran yang diletakkan di Kantor PDAM Kota Salatiga, dapat diketahui adanya keluhan dari pelanggan yang menyangkut tentang pelayanan yang diberikan kepada pelanggan dan juga ada beberapa pelanggan yang berkomentar tentang tingkat pelayanan yang ditawarkan oleh Kantor PDAM Kota Salatiga. Oleh karena itu penelitian ini perlu dilakukan untuk mendapatkan sumber informasi dalam upaya meningkatkan kualitas pelayanan supaya memuaskan pelanggan serta untuk mempertahankan tingkat pelayanan yang menguntungkan bagi pelanggan dan yang berdampak pada loyalitas pelanggan.

Fenomena yang terjadi kesenjangan masalah yaitu mengakibatkan loyalitas pelanggan yang turun disebabkan kepuasan pelanggan yang tidak meningkat dikarenakan kualitas pelayanan yang tidak ditingkatkan. Masih terdapat keluhan dari pelanggan berarti masih terdapat kesenjangan antara apa yang diinginkan oleh pelanggan sebagai pelanggan dengan pelayanan yang telah diberikan. Keluhan-keluhan yang disampaikan oleh pelanggan ditanggapi secara positif Kantor PDAM Kota Salatiga dengan mengambil langkah perbaikan terhadap kualitas pelayanan yang diberikan kepada pelanggan, karena keluhan pelanggan merupakan sebagian dari wujud ketidakpuasan pelanggan sebagai pengguna jasa penyedia air minum pada kantor PDAM Kota Salatiga. Kualitas pelayanan tidak dapat lepas dari kepuasan pelanggan. Pelanggan yang mendapatkan pelayanan yang berkualitas optimal dari puskesmas secara otomatis akan menciptakan kepuasan pelanggan. Didukung oleh hasil penelitian Semuel dan Wijaya (2011), Karsono (2015), Halim (2013), Suasana dkk (2013) yang menunjukkan bahwa aspek keberwujudan, keandalan, ketanggapan, jaminan dan kepedulian yang merupakan dimensi kualitas pelayanan berpengaruh terhadap kepuasan pelanggan.

Kesenjangan antara hasil temuan penelitian-penelitian terdahulu (riset gap), maka dalam penelitian ini akan di uji kembali pengaruh kualitas pelayanan dan kepuasan terhadap loyalitas. Dan beberapa penelitian menunjukkan bahwa kualitas pelayanan dapat mempengaruhi kepuasan maupun loyalitas pelanggan. Kepuasan dan loyalitas sangat diperlukan oleh perusahaan PDAM Kota Salatiga. 
Karena kepuasan yang tinggi, maka pelanggan dapat merasakan kenyamanan sehingga dapat meningkatkan loyalitas pelanggan.

Sehubungan dengan uraian di atas, peneliti ingin melakukan penelitian PDAM di Kota Salatiga terkait dengan kualitas pelayanan yang diberikan oleh perusahaan dalam hubungannya dengan kepuasan pelanggan. Juga hubungan langsung antara kualitas pelayanan terhadap loyalitas, dapat juga berhubungan secara tidak langsung melalui kepuasan. Sementara itu juga ditemukan adanya fenomena yang menunjukkan adanya kesenjangan antara teori dengan kenyataan. Berdasarkan fenomena dan teori tentang kepuasan dan loyalitas di atas menunjukkan adanya kesenjangan (gap) bahwa realitas ternyata tidak mesti sesuai dengan teori-teori yang ada, peneliti berkeinginan untuk melakukan pengujian kembali terkait dengan kualitas pelayanan yang diberikan dalam hubungannya dengan kepuasan pelanggan serta loyalitas pelanggan dengan mengadakan penelitian dengan mengambil judul : Membangun Loyalitas Pelanggan PDAM Kota Salatiga dengan Kualitas Pelayanan Melalui Kepuasan.

\section{HIPOTESIS}

Hipotesis (Sugiyono, 2011: 49) Dapat diartikan sebagai jawaban sementara terhadap rumusan masalah, karena sifatnya masih sementara , maka perlu dibuktikan kebenarannya melalui data empiris yang terkumpul. Dari uraian sebelumnya, maka dapat ditarik hipotesis sebagai berikut :

$\mathrm{H}_{1}$ : Keberwujudan berpengaruh signifikan terhadap kepuasan pelanggan Kantor PDAM Kota Salatiga.

$\mathrm{H}_{2}$ : Keandalan berpengaruh signifikan terhadap kepuasan pelanggan Kantor PDAM Kota Salatiga.

$\mathrm{H}_{3}$ : Ketanggapan berpengaruh signifikan terhadap kepuasan pelanggan Kantor PDAM Kota Salatiga.

$\mathrm{H}_{4}$ : Jaminan berpengaruh signifikan terhadap kepuasan pelanggan Kantor PDAM Kota Salatiga.

$\mathrm{H}_{5}$ : Kepedulian berpengaruh signifikan terhadap kepuasan pelanggan Kantor PDAM Kota Salatiga.

$\mathrm{H}_{6}$ : Keberwujudan berpengaruh signifikan terhadap loyalitas pelanggan Kantor PDAM Kota Salatiga.

$\mathrm{H}_{7}$ : Keandalan berpengaruh signifikan terhadap loyalitas pelanggan Kantor PDAM Kota Salatiga

$\mathrm{H}_{8}$ : Ketanggapan berpengaruh signifikan terhadap loyalitas pelanggan Kantor PDAM Kota Salatiga.

$\mathrm{H}_{9}$ : Jaminan berpengaruh signifikan terhadap loyalitas pelanggan Kantor PDAM Kota Salatiga.

$\mathrm{H}_{10}$ : Kepedulian berpengaruh signifikan terhadap loyalitas pelanggan Kantor PDAM Kota Salatiga.

$\mathrm{H}_{11}$ : Kepuasan pelanggan berpengaruh signifikan terhadap loyalitas pelanggan Kantor PDAM Kota Salatiga.

\section{METODE}

Pengambilan sampel menggunakan teknik simple random sampling dan ditetapkan sebanyak $10 \%$ dari populasi, sehingga diperoleh sampel dengan perhitungan berikut: 1196 x 10\% = 119,6 dibulatkan menjadi 120 sampel. Penelitian ini menggunakan alat analisis berupa uji validitas, uji reliabilitas, uji linieritas, analisa jalur, analisa regresi linier berganda, uji t, uji $\mathrm{F}$ dan koefisien determinasi.

Analisis regresi jalur adalah, analisis jalur merupakan pengembangan langsung bentuk regresi berganda dengan tujuan untuk memberikan estimasi tingkat kepentingan (magnitude) dan signifikasi (significance) hubungan sebab akibat hipotetikal dalam seperangkat variabel.

Hubungan kausalitas akan digunakan analisis jalur dan intervening. Penelitian ini tentang persepsi pelanggan mengenai kualitas pelayanan yang terdiri dari keberwujudan, keandalan, ketanggapan, jaminan, kepedulian terhadap loyalitas dengan kepuasan ditempatkan sebagai variabel intervening.

Analisis regresi linear berganda digunakan untuk menganalisa pengaruh beberapa variabel bebas atau independen variabel $(\mathrm{X})$ terhadap satu variabel tidak bebas atau dependen variabel (Y) sebagai berikut: Persamaan I: $Y_{1}=a+b_{1} X_{1}+b_{2} X_{2}+b_{3} X_{3}+b_{4} X_{4}+b_{5} X_{5}+e_{1}$

Persamaan II : $Y_{2}=a+\beta_{1} X_{1}+\beta_{2} X_{2}+\beta_{3} X_{3}+\beta_{4} X_{4}+\beta_{5} X_{5}+\beta_{6} X_{6}+e_{1}$ 
Keterangan :

$$
\begin{array}{ll}
\mathrm{a} & =\text { Konstanta } \\
\mathrm{X}_{1} & =\text { Keberwujudan } \\
\mathrm{X}_{2} & =\text { Keandalan } \\
\mathrm{X}_{3} & =\text { Ketanggapan } \\
\mathrm{X}_{4} & =\text { Jaminan } \\
\mathrm{X}_{5} & =\text { Kepedulian } \\
\mathrm{Y}_{1} & =\text { Kepuasan Pelanggan } \\
\mathrm{Y}_{2} & =\text { Loyalitas Pelanggan } \\
\beta_{1} \ldots \beta_{5} & =\text { Koefisien regresi } \\
\mathrm{e}_{3} \ldots \mathrm{e}_{3} & =\text { error }
\end{array}
$$

\begin{tabular}{|c|c|c|c|c|c|c|}
\hline \multirow[b]{2}{*}{ Mode } & & \multicolumn{2}{|c|}{$\begin{array}{c}\text { Unstandardized } \\
\text { Coefficients }\end{array}$} & \multirow{2}{*}{$\begin{array}{c}\begin{array}{r}\text { Standardized } \\
\text { Coefficients }\end{array} \\
\text { Beta }\end{array}$} & \multirow[b]{2}{*}{$t$} & \multirow[b]{2}{*}{ Sig. } \\
\hline & & $B$ & Std. Error & & & \\
\hline \multirow[t]{6}{*}{1} & (Constant) & 3,202 & 1,051 & & 3,048 & ,003 \\
\hline & Keberwujudan & ,329 & 039 &, 553 & 8,435 & ,000 \\
\hline & Keandalan &,- 092 & ,066 &,- 093 & $-1,391$ & , 167 \\
\hline & Ketanggapan & 142 & ,055 & 171 & 2,565 & 012 \\
\hline & Jaminan & ,316 & ,056 & ,421 & 5,671 & ,000 \\
\hline & Kepedulian &,- 096 & 070 &,- 102 & $-1,366$ & 175 \\
\hline
\end{tabular}

\begin{tabular}{|c|c|c|c|c|c|c|}
\hline \multirow[b]{2}{*}{ Mod } & & \multicolumn{2}{|c|}{$\begin{array}{c}\text { Unstandardized } \\
\text { Coefficients }\end{array}$} & \multirow{2}{*}{$\begin{array}{c}\text { Standardized } \\
\text { Coefficients }\end{array}$} & \multirow[b]{2}{*}{$t$} & \multirow[b]{2}{*}{ Sig. } \\
\hline & & B & Std. Error & & & \\
\hline \multirow[t]{7}{*}{1} & (Constant) & $-1,044$ & 1,396 & &,- 748 & ,456 \\
\hline & Keberwujudan & 084 & 064 & , 101 & 1,321 & , 189 \\
\hline & Keandalan & ,290 & 085 & ,211 & 3,417 & ,001 \\
\hline & Ketanggapan &,- 237 & ,073 &,- 203 & $-3,257$ & ,001 \\
\hline & Jaminan & ,326 & 081 & ,309 & 4,041 & ,000 \\
\hline & Kepedulian & ,294 & ,090 & ,224 & 3,259 & 001 \\
\hline & Kepuasan Pelanggan & , 485 & , 120 & ,345 & 4,050 & ,000 \\
\hline
\end{tabular}

\section{HASIL PENELITIAN}

Tabel 1.

Hasil Regresi Persamaan Pertama

Coefficients a

\begin{tabular}{|c|c|c|c|c|c|c|}
\hline & & $\begin{array}{l}\text { Sum of } \\
\text { Squares }\end{array}$ & $d f$ & Mean Square & $\mathrm{F}$ & Sig. \\
\hline \multirow[t]{3}{*}{1} & Regression & 302,776 & 6 & 50,463 & 54,260 &, $000^{a}$ \\
\hline & Residual & 105,091 & 113 & ,930 & & \\
\hline & Total & 407,867 & 119 & & & \\
\hline
\end{tabular}

a. Dependent Variable: Kepuasan Pelanggan

Tabel 2.

Hasil Regresi Persamaan Kedua

Coefficients

a. Dependent Variable: Loyalitas

Tabel 3

Hasil Uji F Persamaan kedua

ANOVA

a. Predictors: (Constant), Kepuasan Pelanggan, Keandalan, Ketanggapan, Kepedulian, Keberwujudan, Jaminan

b. Dependent Variable: Loyalitas 
Excellent : Jurnal Manajemen, Bisnis dan Pendidikan

Vol 7, No 2 (2020) ; p.167-181; https://e-journal.stie-aub.ac.id/index.php/excellent

Tabel 4

Koefisien Determinan $\left(\mathrm{R}^{2}\right)$ Persamaan Pertama

\begin{tabular}{|l|c|c|c|c|}
\multicolumn{7}{|c|}{ Model Summary } \\
\hline Model & $\mathrm{R}$ & R Square & $\begin{array}{l}\text { Adjusted } \\
\text { R Square }\end{array}$ & $\begin{array}{c}\text { Std. Error of } \\
\text { the Estimate }\end{array}$ \\
\hline 1 &, $828^{\mathrm{a}}$ &, 686 &, 672 &, 755 \\
\hline
\end{tabular}

a. Predictors: (Constant), Kepedulian, Keberwujudan,

Keandalan, Ketanggapan, Jaminan

Tabel 5

Koefisien Determinan $\left(\mathrm{R}^{2}\right)$ Persamaan Kedua

\begin{tabular}{|l|c|c|c|c|}
\multicolumn{7}{|c|}{ Model Summary } \\
\hline Model & $\mathrm{R}$ & R Square & $\begin{array}{c}\text { Adjusted } \\
\text { R Square }\end{array}$ & $\begin{array}{c}\text { Std. Error of } \\
\text { the Estimate }\end{array}$ \\
\hline 1 &, $862^{\text {a }}$ &, 742 &, 729 &, 964 \\
\hline
\end{tabular}

a. Predictors: (Constant), Kepuasan Pelanggan,

Keandalan, Ketanggapan, Kepedulian, Keberwujudan, Jaminan

b. Dependent Variable: Loyalitas

Tabel 6

Koefisien Korelasi

\begin{tabular}{|c|c|c|c|c|c|c|c|c|}
\hline \multicolumn{9}{|c|}{ Correlations } \\
\hline & & $\begin{array}{c}\text { Keberwuj } \\
\text { udan }\end{array}$ & Keandalan & Ketanggapan & Jaminan & Kepedulian & $\begin{array}{l}\text { Kepuasan } \\
\text { Pelanggan }\end{array}$ & Loyalitas \\
\hline \multirow[t]{3}{*}{ Keberwujudan } & Pearson Correlation & 1 &, $499^{* *}$ & $316^{* *}$ &, $539 * *$ &, $440^{* *}$ & ,742* &, $663^{* *}$ \\
\hline & Sig. (2-tailed) & & , 000 & ,000 & , 000 & ,000 & ,000 & , 000 \\
\hline & $\mathrm{N}$ & 120 & 120 & 120 & 120 & 120 & 120 & 120 \\
\hline \multirow[t]{3}{*}{ Keandalan } & Pearson Correlation & ,499** & 1 &, $435^{* *}$ &, $534^{* *}$ &, $476^{*+1}$ &, $433^{* *}$ &, $593^{* *}$ \\
\hline & Sig. (2-tailed) & ,000 & & ,000 & ,000 & ,000 & ,000 & ,000 \\
\hline & $\mathrm{N}$ & 120 & 120 & 120 & 120 & 120 & 120 & 120 \\
\hline \multirow[t]{3}{*}{ Ketanggapan } & Pearson Correlation & $316^{* *}$ &, $435^{* *}$ & 1 & ,456*t &, $586^{* *}$ &, $437^{* *}$ & $343^{* *}$ \\
\hline & Sig. (2-tailed) & ,000 & ,000 & & , 000 & 000 &, 000 & ,000 \\
\hline & $\mathrm{N}$ & 120 & 120 & 120 & 120 & 120 & 120 & 120 \\
\hline \multirow[t]{3}{*}{ Jaminan } & Pearson Correlation &, $539^{* *}$ &, $534^{* *}$ &, $456^{* * 2}$ & 1 & ,612**t| & ,684*t. & ,756** \\
\hline & Sig. (2-tailed) & ,000 & ,000 & ,000 & & ,000 & ,000 & ,000 \\
\hline & $\mathrm{N}$ & 120 & 120 & 120 & 120 & 120 & 120 & 120 \\
\hline \multirow[t]{3}{*}{ Kepedulian } & Pearson Correlation &, $440^{* *}$ &, $476^{* *}$ &, $586^{* *}$ & ,612**t| & 1 & ,455** &, $595^{* *}$ \\
\hline & Sig. (2-tailed) &, 000 & , 000 &, 000 & ,000 & &, 000 &, 000 \\
\hline & $\mathrm{N}$ & 120 & 120 & 120 & 120 & 120 & 120 & 120 \\
\hline \multirow[t]{3}{*}{ Kepuasan Pelanggan } & Pearson Correlation & ,742** & ,433*+ & ,437**t| & ,684*t| & ,455*t & 1 & ,735** \\
\hline & Sig. (2-tailed) & ,000 & ,000 & ,000 & , 000 & ,000 & & ,000 \\
\hline & $\mathrm{N}$ & 120 & 120 & 120 & 120 & 120 & 120 & 120 \\
\hline \multirow[t]{3}{*}{ Loyalitas } & Pearson Correlation & ,663*t &, $593^{* *}$ & $343^{* * 2}$ &, $756 * *$ &, $595^{* *}$ & ,735** & 1 \\
\hline & Sig. (2-tailed) & ,000 & ,000 & ,000 & ,000 & ,000 &, 000 & \\
\hline & $\mathrm{N}$ & 120 & 120 & 120 & 120 & 120 & 120 & 120 \\
\hline
\end{tabular}

Berdasarkan hasil analisa jalur dapat diperoleh hasil sbb:

Persamaan 1 yaitu :

$\mathrm{Y}_{1}=0,553 \mathrm{X} 1-0,093 \mathrm{X} 2+0,171 \mathrm{X} 3+0,421 \mathrm{X} 4-0,102 \mathrm{X} 5+\epsilon 1$

Sig $\quad(0,000)^{* *}(0,167) \quad(0,012)^{* *} \quad(0,000)^{* *} \quad(0,175)$

Persamaan 2 yaitu :

$Y_{2}=0,101 X_{1}+0,211 X_{2}-0,203 X_{3}+0,309 X_{4}+0,224 X+0,345 X_{6}+\epsilon_{1}$

Sig $\quad(0,189) \quad(0,001)^{* *}(0,001)^{* *} \quad(0,000)^{* *}(0,001)^{* *} \quad(0,000)^{* *}$ 


\section{Model Hasil Analisis:}

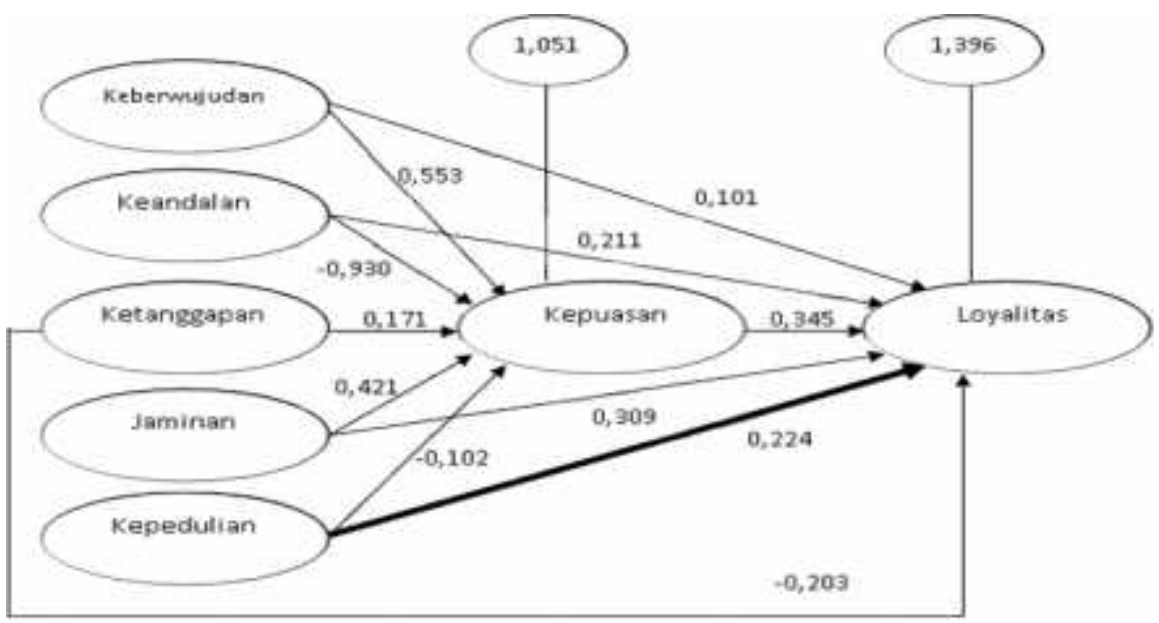

\section{Gambar 1.}

Pengaruh langsung, Tidak Langsung, dan Total Pengaruh

\section{PEMBAHASAN}

1. Pengaruh Keberwujudan terhadap loyalitas

Hasil analisis jalur menunjukkan bahwa pengaruh tidak langsung keberwujudan terhadap loyalitas pelanggan melalaui kepuasan lebih besar dibanding dengan pengaruh langsung, sehingga untuk meningkatkan loyalitas pelanggan lebih efektif melalui jalur tidak langsung melalui kepuasan. Hasil ini sesuai dengan penelitian yang dilakukan oleh Karsono (2015), Suasana dkk (2013), Semuel dan Wijaya (2011), Halim (2013), yang menunjukkan bahwa keberwujudan sebagai salah satu dimensi kualitas pelayanan berpengaruh terhadap kepuasan dan kepuasan terhadap loyalitas pelanggan.

Upaya untuk meningkatkan keberwujudan dengan cara melihat hasil analisis validitas yaitu dari 5 item pertanyaan, skor tertinggi yaitu nomor 2, 5, 3, 1, 4 adalah sebagai berikut:

a. Meningkatkan tempat pelayanan, sehingga nyaman dan bersih

b. Meningkatkan ruang tunggu di Kantor PDAM Kota Salatiga

c. Meningkatkan tersedianya tempat tunggu yang nyaman

d. Meningkatkan sarana peralatan yang di gunakan untuk memberikan pelayanan sehingga memadai dan cukup lengkap

e. Meningkatkan Penampilan karyawan di Kantor PDAM Kota Salatiga.

Upaya untuk meningkatkan kepuasan dengan cara melihat hasil analisis validitas yaitu dari 5 item pertanyaan, skor tertinggi yaitu nomor 4, 1, 3, 2 adalah sebagai berikut:

a. Meningkatkan ketanggaan karyawan dalam pelayanan membantu kesulitan pelanggan

b. Meningkatkan fasilitas langsung yang diberikan kepada pelanggan.

c. Meningkatkan kemampuan karyawan dalam menangani keluhan masyarakat

d. Meningkatkan kemampuan karyawan dalam melayani semua pelanggan

2. Pengaruh Keandalan terhadap loyalitas

Hasil analisis jalur menunjukkan bahwa pengaruh langsung keandalan terhadap loyalitas pelanggan lebih besar dibanding dengan pengaruh tidak langsung, sehingga untuk meningkatkan loyalitas pelanggan lebih efektif melalui jalur langsung. Hasil ini sesuai dengan penelitian yang dilakukan oleh Karsono (2015), Suasana dkk (2013), Semuel dan Wijaya (2011), Halim (2013), yang menunjukkan bahwa kendalan sebagai salah satu dimensi kualitas pelayanan berpengaruh terhadap loyalitas pelanggan 
Upaya untuk meningkatkan keandalan dengan cara melihat hasil analisis validitas variabel keandalan dapat diketahui nilai $r$ tertinggi yaitu pada nomor 1, 2, 4, 3 adalah sebagai berikut:

a. Meningkatkan prosedur pelayanan kepada pelanggan dengan baik

b. Meningkatkan sikap baik dan sopan terhadap pelanggan

c. Meningkatkan keandalaan dan kepercayaaan terhadap pelanggan

d. Meningkatkan ketepatan dalam pelayanan kepada pelanggan dengan teliti dan tepat

3. Pengaruh Ketanggapan terhadap loyalitas

Hasil analisis jalur menunjukkan bahwa pengaruh tidak langsung ketanggapan terhadap loyalitas pelanggan melalaui kepuasan lebih besar dibanding dengan pengaruh langsung, sehingga untuk meningkatkan loyalitas pelanggan lebih efektif melalui jalur tidak langsung melalui kepuasan. Hasil ini sesuai dengan penelitian yang dilakukan oleh Karsono (2015), Suasana dkk (2013), Semuel dan Wijaya (2011), Halim (2013), yang menunjukkan bahwa ketanggapan sebagai salah satu dimensi kualitas pelayanan berpengaruh terhadap kepuasan dan kepuasan terhadap loyalitas pelanggan.

Upaya untuk meningkatkan ketanggapan dengan cara melihat hasil analisis validitas yaitu dari 5 item pertanyaan, skor tertinggi yaitu nomor 4, 2, 1, 3, 5 adalah sebagai berikut:

a. Meningkatkan usaha untuk memenuhi permintaan pelanggan

b. Meningkatkan usaha untuk memberikan pelayanan dengan kesungguhan kepada pelanggan

c. Meningkatkan dengan tanggap terhadap keluhan pelanggan

d. Meningkatkan usaha untuk memberikan solusi terhadap masalah yang di hadapi pelanggan

e. Meningkatkan kesanggupan membantu permasalahan yang di hadapi pelanggan.

Upaya untuk meningkatkan kepuasan dengan cara melihat hasil analisis validitas yaitu dari 5 item pertanyaan, skor tertinggi yaitu nomor 4, 1, 3, 2 adalah sebagai berikut:

a. Meningkatkan kepuasan karena karyawan cepat tanggap dalam pelayanan membantu kesulitan pelanggan

b. Meningkatkan kepuasan terhadap fasilitas langsung yang diberikan oleh Kantor PDAM Kota Salatiga

c. Meningkatkan kepuasan terhadap kemampuan Karyawan Kantor PDAM Kota Salatiga dalam menangani keluhan masyarakat

d. Meningkatkan kepuasan terhadap kemampuan karyawan Kantor PDAM Kota Salatiga dalam melayani semua pelanggan.

4. Pengaruh Jaminan terhadap loyalitas

Hasil analisis jalur menunjukkan bahwa pengaruh langsung jaminan terhadap loyalitas pelanggan lebih besar dibanding dengan pengaruh tidak langsung, sehingga untuk meningkatkan loyalitas pelanggan lebih efektif melalui jalur langsung, dan kepedulian merupakan pengaruh yang paling dominan dalam mempengaruhi loyalitas pelanggan PDAM Kota Salatiga. Hasil ini sesuai dengan penelitian yang dilakukan oleh Karsono (2015), Suasana dkk (2013), Semuel dan Wijaya (2011), Halim (2013) yang menunjukkan bahwa jaminan sebagai salah satu dimensi kualitas pelayanan berpengaruh terhadap loyalitas pelanggan

Upaya untuk meningkatkan jaminan dengan cara melihat hasil analisis variabel jaminan diketahui nilai $r$ tertinggi pada nomor 5, 4, 1, 2, 3 adalah sebagai berikut:

a. Meningkatkan kemampuan pengetahuan ketrampilan untuk melaksanakan pekerjaan dengan baik

b. Meningkatkan kemampuan selalu menjaga hubungan yang baik terhadap pelanggan

c. Meningkatkan tanggung jawab yang baik terhadap tugas-tugasnya

d. Meningkatkan kemampuan yang memadai di bidangnya

e. Meningkatkan usaha dalam bersikap ramah terhadap pelanggan 
5. Pengaruh Kepedulian terhadap loyalitas

Hasil analisis jalur menunjukkan bahwa pengaruh langsung kepedulian terhadap loyalitas pelanggan lebih besar dibanding dengan pengaruh tidak langsung, sehingga untuk meningkatkan loyalitas pelanggan lebih efektif melalui jalur langsung. Hasil ini sesuai dengan penelitian yang dilakukan oleh Karsono (2015), Suasana dkk (2013), Semuel dan Wijaya (2011), Halim (2013) yang menunjukkan bahwa kepedulian sebagai salah satu dimensi kualitas pelayanan berpengaruh terhadap loyalitas pelanggan

Upaya untuk meningkatkan kepedulian dengan cara melihat hasil analisis variabel kepedulian diketahuii skor tertinggi yaitu pada nomor 4, 2, 1, 3. Langkah-langkah yang perlu dilakukan adalah sebagai berikut:

a. Meningkatkan kemampuan memberikan penjelasan dan pengetahuan dalam pelayanan

b. Meningkatkan kemampuan dalam memberikan layanan tanpa pandang bulu atau pilih kasih

c. Meningkatkan Perhatian/Empati terhadap semua pelanggan yang datang

d. Meningkatkan perhatian yang tulus dalam pelayanan

\section{PENUTUP}

\section{Simpulan}

1. Berdasarkan analisis data dan kesimpulan pengujian hipotesis, maka dalam penelitian ini dapat diambil kesimpulan dari uji t sebagai berikut Keberwujudan berpengaruh positif dan signifikan terhadap kepuasan pelanggan PDAM Kota Salatiga.

a. Keandalan berpengaruh negatif dan tidak signifikan terhadap kepuasan pelanggan PDAM Kota Salatiga.

b. Ketanggapan berpengaruh positif dan signifikan terhadap kepuasan pelanggan PDAM Kota Salatiga.

c. Jaminan berpengaruh positif dan signifikan terhadap kepuasan pelanggan PDAM Kota Salatiga.

d. Kepedulian berpengaruh negatif dan tidak signifikan terhadap kepuasan pelanggan PDAM Kota Salatiga.

e. Keberwujudan berpengaruh positif dan tidak signifikan terhadap loyalitas pelanggan PDAM Kota Salatiga.

f. Keandalan berpengaruh positif dan signifikan terhadap loyalitas pelanggan PDAM Kota Salatiga.

g. Ketanggapan berpengaruh negatif dan signifikan terhadap loyalitas pelanggan PDAM Kota Salatiga.

h. Jaminan berpengaruh positif dan signifikan terhadap loyalitas pelanggan PDAM Kota Salatiga.

i. Kepedulian berpengaruh positif dan signifikan terhadap loyalitas pelanggan PDAM Kota Salatiga.

j. Kepuasan berpengaruh positif dan signifikan terhadap loyalitas pelanggan PDAM Kota Salatiga.

2. Dari hasil uji ANOVA atau $\mathrm{F}$ test, model regresi dapat dipakai untuk memprediksi loyalitas pelanggan di PDAM Kota Salatiga atau dengan kata lain kepuasan, kepedulian, keberwujudan, ketanggapan, keandalan, jaminan secara simultan/bersama-sama berpengaruh signifikan terhadap loyalitas pelanggan di PDAM Kota Salatiga.

3. Nilai $\mathrm{R}^{2}$ total sebesar 0,919 dapat diartikan variasi loyalitas pelanggan PDAM Kota Salatiga dijelaskan oleh variabel keberwujudan, keandalan, ketanggapan, jaminan, kepedulian, dan kepuasan pelanggan sebesar $91,9 \%$ sisanya sebesar 7,1\% dijelaskan oleh variabel lain di luar model penelitian, seperti lokasi, harga dan lain-lain. 
4. Kesimpulan pengaruh langsung dan tidak langsung

a. Keberwujudan lebih efektif melalui jalur tidak langsung melalui kepuasan, karena hasil pengaruh tidak langsung lebih besar dari pada pengaruh langsung.

b. Keandalan lebih efektif melalui jalur langsung, karena hasil pengaruh langsung lebih besar dari pada pengaruh tidak langsung.

c. Ketanggapan lebih efektif melalui jalur tidak langsung, karena hasil pengaruh langsung lebih kecil dari pada pengaruh tidak langsung.

d. Jaminan lebih efektif melalui jalur langsung, karena hasil pengaruh langsung lebih besar dari pada pengaruh tidak langsung.

e. Kepedulian lebih efektif melalui jalur langsung, karena hasil pengaruh langsung lebih besar dari pada pengaruh tidak langsung..

f. Hasil analisis jalur dapat diketahui bahwa pengaruh langsung Jaminan terhadap loyalitas pelanggan di PDAM Kota Salatiga merupakan jalur yang paling efektif atau dominan.

\section{SARAN}

Berdasarkan hasil penelitian, maka saran yang dapat diberikan dalam penelitian ini adalah sebagai berikut:

1. Berdasarkan hasil penelitian yang sudah dilakukan, diketahui pengaruh variable jaminan terhadap loyalitas mempunyai nilai paling tinggi, sehingga jaminan dapat lebih menjadi perhatian bagi PDAM Kota Salatiga. Kegiatan ini dapat dilakukan dengan cara sebagai berikut :

a. Meningkatkan kemampuan pengetahuan ketrampilan untuk melaksanakan pekerjaan dengan baik

Meningkatkan keterampilan kerja dengan mengikuti kursus di lembaga pendidikan nonformal. Kursus yang diikuti bisa membantu untuk mengembangkan pengetahuan teoritis dan praktis yang dibutuhkan untuk meningkatkan kemampuan pengetahuan ketrampilan.

b. Meningkatkan kemampuan selalu menjaga hubungan yang baik terhadap pelanggan

Kunci untuk membangun hubungan jangka panjang adalah penciptaan nilai dan kepuasan pelanggan yang setia dengan memberikan pelayanan terbaik, dan pelanggan yang setia lebih cenderung akan memberi perusahaan pangsa yang lebih besar dari bisnis mereka.

c. Meningkatkan tanggung jawab yang baik terhadap tugas-tugasnya

Pimpinan harus mendorong karyawan agar selalu bertanggung jawab penuh atas setiap tugas yang diberikan dan memberikan target dan standar pekerjaan

d. Meningkatkan kemampuan yang memadai di bidangnya

Seseorang karyawan yang memiliki kemampuan, pengetahuan dan keilmuan di bidang yang dia geluti, jika dalam pelayanan terhadap para pelanggan terdapat masalah tertentu maka setidaknya mulai lebih mawas diri dan mempelajari apapun yang belum dikuasai.

e. Meningkatkan usaha dalam bersikap ramah terhadap pelanggan

Berempati tidak hanya sekedar simpati. Terlebih dari itu untuk kondisi-kondisi tertentu seorang karyawan harus bisa memberikan kepedulian dan perhatian yang mendalam terhadap pelanggan. Senyum adalah hal sepele namun terkadang sangat sulit untuk dilakukan. Dengan tersenyum otomatis memancarkan energi positif terhadap orang lain.

2. Pengaruh variabel kepedulian terhadap loyalitas mempunyai nilai yang kedua. Upaya untuk meningkatkan kepedulian dengan cara :

a. Meningkatkan kemampuan memberikan penjelasan dan pengetahuan dalam pelayanan

Memastikan bahwa kamu telah mengidentifikasi kebutuhan pelanggan dengan baik dan benar.

Berikan penjelasan yang benar dengan apa yang bisa diberikan, lakukan tindak lanjut untuk memastikan setiap produk dan layanan sesuai dengan target pelayanan yang ada. 
b. Meningkatkan kemampuan dalam memberikan layanan tanpa pandang bulu atau pilih kasih Para pelanggan mungkin ada yang marah, memiliki banyak pertanyaan untuk customer service, dan terkadang memiliki sikap yang menjengkelkan. Sebagai seorang customer service, kamu harus mengetahui bagaimana cara untuk menangani sikap yang dilakukan para pelanggan dan memberikan pelayanan yang sama kepada mereka tanpa pandang bulu atau pilih kasih.

c. Meningkatkan Perhatian/Empati terhadap semua pelanggan yang datang

Beberapa strategi yang berkaitan dengan upaya untuk membangun hubungan yang baik dengan pelanggan adalah berikan sikap yang tulus untuk memberikan layanan terbaik kepada para pelanggan. Jadilah orang yang mendengar dan mampu mengerti dengan apa yang diinginkan para pelanggan, dan kamu harus mampu memposisikan diri seolah-olah sebagai pelanggan.

d. Meningkatkan perhatian yang tulus dalam pelayanan

Jika pelanggan membutuhkan informasi maka kamu harus memberikan informasi sejelas mungkin kepada mereka. Namun jika kebutuhan para pelanggan harus diselesaikan ditempat lain, kamu juga harus membantu dalam memahami kepada siapa mereka harus bertanya dan meminta bantuan.

3. Pengaruh variabel keandalan terhadap loyalitas mempunyai nilai yang ketiga. Upaya untuk meningkatkan keandalan dengan cara :

a. Meningkatkan prosedur pelayanan kepada pelanggan dengan baik

Pastikan karyawan sudah terlatih sebelum mulai bekerja, agar mereka mengetahui tugas serta kewajibannya dalam pelayanan kepada pelanggan. Jika perlu, agendakan training atau pelatihan secara rutin setiap beberapa bulan sekali, agar mereka lebih memahami lagi tentang tugas dan kewajibannya dalam pelayanan kepada pelanggan.

b. Meningkatkan sikap baik dan sopan terhadap pelanggan

Komunikasi dengan pelanggan harus dilakukan dengan sikap yang baik dan sopan agar pelanggan nyaman dengan pelayanan yang diberikan. Sikap yang baik dan sopan harus selalu di kedepankan, walaupun yang dihadapi adalah pelanggan yang membuat kesal. Jika perlu adakan training terutama untuk mengajarkan nilai-nilai kesopanan terhadap semua karyawan, terutama yang terlibat langsung dengan pelanggan.

c. Meningkatkan keandalaan dan kepercayaaan terhadap pelanggan

Apabila dapat terus menerus mempertahankan dan meningkatkan kualitas pelayanan maka diharapkan akan berdampak terhadap peningkatkan nilai tambah bagi pelanggan. Semakin banyak pelanggan yang mendapatkan nilai tambah pelayanan yang baik dari perusahaan sudah dipastikan bahwa kepercayaaan pelanggan juga akan meningkat

d. Meningkatkan ketepatan dalam pelayanan kepada pelanggan dengan teliti dan tepat

Pahami inti permasalahan yang dihadapi pelanggan, kemudian menawarkan solusi yang tepat untuk mengatasinya. Sampaikan solusi - solusi kepada pelanggan dan konfirmasikan apakah solusi tersebut dapat menyelesaikan masalah pelanggan tersebut

4. Pengaruh variabel keberwujudan terhadap loyalitas mempunyai nilai yang keempat. Upaya untuk meningkatkan keberwujudan dengan cara :

a. Meningkatkan tempat pelayanan, sehingga nyaman dan bersih

Peningkatan dengan menjaga kebersihan tempat pelayanan dan peletakan barang - barang sehingga tidak terlihat berantakan. Pastikan juga bahwa segala hal yang tidak dibutuhkan (termasuk sampah) untuk selalu rajin dibersihkan. Simpan juga dengan barang - barang yang tidak perlu dibuang, namun mungkin dibutuhkan di lain waktu supaya tempat tetap terlihat rapi dan bersih. 
b. Meningkatkan ruang tunggu di Kantor PDAM Kota Salatiga

Penambahan akses internet di ruang tunggu dan pemasangan fasilitas wifi di lingkungan sekitar. Jika selama ini para penumpang yang ingin menikmati fasilitas yang 'lebih' memilih untuk menggunakan executive lounge dimana mereka sambil menunggu antrian dapat menikmati makanan ringan, minuman panas dan dingin serta akses gratis ke internet, maka dengan perbaikan dan peningkatan kualitas ruang tunggu, semua penumpang dapat menikmati fasilitas tersebut tanpa harus membayar lagi. Dan waktu menunggu panggilan antrian akan menjadi sesuatu yang tak lagi membosankan

c. Meningkatkan tersedianya tempat tunggu yang nyaman

Peningkatan ruang tunggu yang bersih dan rapi, berpenyejuk udara (AC) yang dingin, serta suasana yang tidak berisik membuat pelanggan merasa nyaman menunggu saat antrian. Demikian juga dengan penempatan kursi yang banyak yang membuat pelanggan tidak berdesak - desakan menunggu saat antrian..

d. Meningkatkan sarana peralatan yang di gunakan untuk memberikan pelayanan sehingga memadai dan cukup lengkap

Bukti fisik merupakan kemampuan suatu perusahaan dalam menunjukkan eksistensinya kepada para pelanggan, penampilan dan kemampuan sarana dan prasarana fisik sebuah perusahaan dan keadaan lingkungan sekitarnya adalah bukti nyata dari pelayanan yang diberikan oleh pemberi jasa. Bukti fisik tersebut meliputi penampilan fasilitas fisik, peralatan, personil, dan materi komunikasi.

e. Meningkatkan Penampilan karyawan di Kantor PDAM Kota Salatiga.

Penampilan fisik adalah hal yang penting. Meningkatkan penampilan yang rapi, bersih dan profesional akan memberikan kesan yang baik bagi pelanggan. Selalu berpenampilan rapi, bersih dan profesional akan membuat lebih percaya diri saat akan bertemu dengan pelanggan.

5. Pengaruh variabel ketanggapan terhadap loyalitas mempunyai nilai yang kelima. Upaya untuk meningkatkan ketanggapan dengan cara :

a. Meningkatkan usaha untuk memenuhi permintaan pelanggan

Perencanaan atas permintaan konsumen merupakan bagian dari proses penjualan dan perencanaan operasional. Bukan suatu proses yang berdiri sendiri (Stand Alone). Buat rencana perusahaan yang mengintegrasikan aktivitas lintas-perusahaan dan mendorong kemajuan potensi perusahaan ke depan untuk memenuhi permintaan pelanggan dengan baik.

b. Meningkatkan usaha untuk memberikan pelayanan dengan kesungguhan kepada pelanggan Menganalisis dan mengategorikan permintaan pelanggan atas dasar jenis produk, tipe pelanggan atau daerah geografis. Buat cara atau strategi yang unik untuk memprediksi dan merencanakan permintaan pelanggan. Dan bersiaplah untuk mengubah cara merencanakan dan memprediksi permintaan pelanggan sesuai dengan perubahan-perubahan yang bersifat "eksternal"

c. Meningkatkan dengan tanggap terhadap keluhan pelanggan

Keluhan dari pelanggan sebetulnya dapat menjadi peluang untuk meningkatkan kualitas pelayanan. Seorang pelanggan akan tetap melakukan transaksi walau baru saja perusahaan melakukan kesalahan. Pahami inti keluhan yang dihadapi pelanggan dan meminta maaf karenanya, kemudian menawarkan solusi yang tepat untuk mengatasinya. Jelaskan solusinya kepada pelanggan dan konfirmasikan apakah solusi tersebut dapat menyelesaikan masalah mereka.

d. Meningkatkan usaha untuk memberikan solusi terhadap masalah yang di hadapi pelanggan Penerapan solusi kepada pelanggan harus menjadi pengalaman yang efisien bagi perusahaan. Misalnya, Disaat menunggu antrian pelanggan menyampaikan keluhan karena server jaringan 
website mendadak down. Pastikan pelanggan tahu bahwa Anda memahami betapa mendesaknya masalah tersebut dan akan segera memperbaikinya dalam beberapa jam. Ingatlah bahwa jika sistem IT perusahaan down, bukan hanya pelanggan yang merasakan dampaknya, tetapi juga Anda. Produktivitas karyawan akan berkurang dan berpengaruh pada performa kinerja. Dalam hal ini, komplain dari pelanggan pun dapat berfungsi sebagai "alarm" bagi Perusahaan.

e. Meningkatkan kesanggupan membantu permasalahan yang di hadapi pelanggan

Begitu mendengarkan keluhan yang disampaikan pelanggan, harus bisa memahami dengan baik masalah apa yang sebetulnya dihadapi pelanggan. Setelah itu, lakukan analisis secara cepat, solusi apa yang perlu ditawarkan dan terapkan. Itulah mengapa penting untuk mencatat dan menganalisis setiap komplain yang masuk dan cara-cara yang dilakukan untuk menanganinya. Jika ada satu komplain yang terus menerus disampaikan pelanggan, jadikan hal tersebut sebagai peringatan keras bahwa harus mengambil tindakan serius.

6. Upaya untuk meningkatkan kepuasan dengan cara :

a. Meningkatkan kepuasan karena karyawan cepat tanggap dalam pelayanan membantu kesulitan pelanggan

Seorang karyawan customer service tidak hanya terbatas untuk memenuhi keinginan para pelanggan. Tetapi juga membantu setiap permasalahan yang dimiliki oleh pelanggan. Namun, permasalahan yang dibantu masih berkaitan dengan permasalahan umum dan bukan permasalahan pribadi pelanggan. Hal ini berkaitan dengan memberikan lebih dari ekspektasi dan memecahkan setiap pemasalahan yang dimiliki para pelanggan.

b. Meningkatkan kepuasan terhadap fasilitas langsung yang diberikan oleh Kantor PDAM Kota Salatiga

Dalam memberikan pelayanan, setiap karyawan diharapkan mampu menguasai produk atau jasa yang dimiliki dan juga memahami dengan baik seluk beluk perusahaan dan juga dengan pelanggan yang sedang dihadapi. Sehingga perusahaan akan mampu untuk memberikan pelayaan yang memuaskan dan disukai para pelanggan.

c. Meningkatkan kepuasan terhadap kemampuan Karyawan Kantor PDAM Kota Salatiga dalam menangani keluhan masyarakat

Setiap pelanggan memiliki sikap dan permasalahan yang yang berbeda - beda yang harus dihadapi. Belum lagi, sikap dan permasalahan mereka mungkin saja berubah dari minggu ke minggu. Oleh karena itu, kamu harus mampu mencoba untuk bisa menangani setiap sikap dan permasalahan yang ada dan mampu merasakan suasana hati para pelanggan.

d. Meningkatkan kepuasan terhadap kemampuan karyawan Kantor PDAM Kota Salatiga dalam melayani semua pelanggan.

Seorang karyawan harus mampu untuk mengikuti alur pembicaraan saat berkomunikasi dengan pelanggan. Komunikasi yang lancar dapat terwujud di saat Seorang karyawan customer service dapat memahami apa kemauan dan permintaan yang diinginkan para pelanggan. Jika kamu tidak memahami maksud yang diinginkan para pelanggan, maka bukan tidak mungkin kamu tidak bisa melakukan aksi yang tepat terhadap apa yang diinginkan pelanggan. 


\section{DAFTAR PUSTAKA}

Anindhyta (2014), Pengaruh Kualitas Layanan Dan Penanganan Keluhan Terhadap Kepuasan Dan Loyalitas Nasabah Bank Umum Syariah Di Surabaya, Jurnal Bisnis dan Manajemen Vol. 4 No. 10, Pp. $45-56$

Arikunto, Suharsimi, 2011. Prosedur Penelitian Suatu Pendekatan Praktek, Edisi Ketiga. pp.109

Dharmesta, Basu Swastha. 2009, “Loyalitas Pasien : Sebuah kajian konseptual sebagai panduan bagi peneliti," Jurnal Ekonomi dan Bisnis Indonesia, Vol.14, No.3.

Fournier and Yao, 2011, Customer Behavior, Eighth Edition, The Dryden Press, Harcount Brace College Publishers

Ghozali, Imam, 2014, Analisis Multivariat, Badan penerbit Undip, Semarang.

Gujarati, Damodar. 2012. Ekonometrika Dasar. Erlangga. Jakarta

Halim (2013), Analisis Hubungan antara Service Quality, Customer Satisfaction dan Switching Cost terhadap Customer Loyalty: Studi Kasus Perpindahan GSM ke CDMA Mahasiswa di Depok, Jurnal Usahawan, No. 3 TH XXXVII, hal. 42 - 52

Henning dan Klee, 2012, The relationship between organizational culture, leadership and worker motivation toward the performance of educations. Indian Journal of Health and Welbeing, $4(1), 110-112$

Irawan, Handi. 2012. 10 Prinsip Kepuasan Pelanggan. Jakarta. Elex Media. Komputindo

Karsono. 2015. Kualitas pelayanan terhadap loyalitas anggota dengan kepuasan anggota sebagai variabel pemediasi. Jurnal Bisnis \& Manajemen, Vol. 5, No. 2, hal. 183-196

Kotler, Philip , 2011, Manajemen Pemasaran, Edisi Millenium, Jakarta Prenhalindo.

Kotler. Philip, Keller and Kevin Lane. 2013; Dasar-Dasar Pemasaran - Principles of marketing, edisi XII, Jakarta.

Kuncoro, Mudrajad, 2011, metode Kuantitatif : Teori dan Aplikasi untuk Bisnis dan Ekonomi, Edisi I, AMP YKPN, Yogyakarta.

Lupiyoadi, Rambat 2013; Manajement Pemasaran Jasa, Teori dan Praktek, Jakarta.

Fajar. Muhammad Ibnu dan Hasibuan. Rahman, 2011. Pengaruh pelayanan dan kepuasan pasien terhadap loyalitas pasien rawat inap dan rawat jalan di Rumah Sakit Embung Fatimah Kota Batam. Studi Kasus Pada Mahasiswa Fakultas Ekonomi Universitas Riau Kepulauan Angkatan Tahun 2011.

Muninjaya, Gde AA, 2011, Manajemen Mutu Pelayanan Kesehatan, Jakarta, EGC

Parasuraman, A.,V.A Zeityhaml, and L.L Berry. 2010, “ A Conceptual Model of Service Quality And Implication F or F utrure Research", Journal Of Marketing, Vo.49, p.40.50

Putu, Nyoman Dan Abdullah. 2013, Pengaruh Kualitas Pelayanan Terhadap Kepuasan Dan Loyalitas Pasien Tegal Sari Accommodation Di Ubud. Jurnal Ilmu Administrasi Dan Organisasi, Volume 17, Nomor 2 Hlm. 104-128

Pohan, 2013. Jaminan Mutu Pelayanan Kesehatan. Kesaint Blane : Bekas 
Pramana. 2010, Pengaruh kualitas pelayanan terhadap kepuasan dan loyalitas siswa di RSUD Karanganyar. Jurnal Ilmu Administrasi Dan Organisasi, Mei-Agus 2010, Volume 17, Nomor 2 Hlm. 104-128

Peter, J. Paul, Olson, Jerry C, 2010, Consumer Behavior and Marketing Strategy 9th edition, McGraw-Hill Higher Education, New York

Riduwan.2014. Skala Pengukuran variabel-variabel penelitian.Cetakan ketiga. Alfabeta. Bandung.

Rosinta dkk. 2010. Pengaruh Kualitas Layanan Terhadap Kepuasan Pelanggan Dalam Membentuk Loyalitas Pelanggan. Jurnal Ilmu Administrasi Dan Organisasi, Mei-Agus 2010, Volume 17, Nomor 2 Hlm. 114-126

Sadalia. Aditi, B dan R. I. 2013. "Pengaruh Kualitas Layanan terhadap Kepuasan Menabung serta Dampaknya terhadap Loyalitas Menabung pada Nasabah PT. Bank Sumut Cabang Iskandar Muda Medan.” Jurnal EKSIS. ISSN: 2302-1489. Vol. 1, No. 4.

Sugiyono, 2011. Metodologi Penelitian Bisnis, Cetakan Keenam, CV. Alpabeta, Bandung.

Semuel dan Wijaya. 2011, Service Quality, Perceive Value, Satisfaction, Trust dan Loyalty Pada PT. Kereta Api Indonesia Menurut Penilaian Masyarakat Surabaya. Jurnal Manajemen Pemasaran Vol. 4, No. 1, hal. 23 - 37

Suasana dkk. 2013. Pengaruh Kualitas Layanan terhadap Kepuasan dan Loyalitas Pelanggan Garuda Indonesia di Denpasar. Jurnal Manajemen, Strategi Bisnis, dan Kewirausahaan. Volume 7, Nomor 1

Suparno, 2011. Path Analysis untuk data kuantitatif. Pustaka Pelajar, Yogyakarta.

Supranto J, 2011, Pengukuran Tingkat Kepuasan Pasien RSUD BOYOLALI, Rineka Cipta, Jakarta

Suhartadi. 2014, Pengaruh kualitas pelayanan dan Bauran Ritel terhadap Customer Switching Behaviour dan Loyalitas melalui Kepuasan pada Pelanggan Alfamart di Kota Jember, Http// repository.widyatama.ac.id, Fakultas Bisnis Manajemen Universitas Widyatama Bandung

Sri Fitriani, 2014. Pengaruh Kualitas Pelayanan Terhadap Loyalitas Melalui Kepuasan Pasien Pengguna BPJS Di Rawat Inap RSUD Dr. Moewardi. Naskah Publikasi Program Studi Magister Manajemen Program Pascasarjana Universitas Muhammadiyah Surakarta 2014.

Syah dkk. 2017, The Effect of Service Quality on Loyalty with Mediation of Patient Satisfaction, International Journal of Business and Management Invention.Volume 6 Issue 3 || March. 2017 || $P P-41-50$.

Tjiptono, Fandi, 2012, Prinsip-prinsip Total Quality Service (TQS), Andi Offset, Yogyakarta. Undang-undang dasar 1945 Pasal 33 ayat (3) 